\title{
Women, Gender and the evolving tactics of Boko Haram
}

\section{by Jacob Zenn and Elizabeth Pearson}

\section{(cc) BY}

This work is licensed under a Creative Commons Attribution 3.0 License.

\begin{abstract}
This article addresses an under-researched aspect of Boko Haram's activities: gender-based violence (GBV) and its targeting of women. It argues that 2013 marked a significant evolution in Boko Haram's tactics, with a series of kidnappings, in which one of the main features was the instrumental use of women. This was in response to corresponding tactics by the Nigerian security forces. Additionally the analysis provides evidence of a shift by Boko Haram to include women in its operations, in response to increased pressure on male operatives. It also considers the gendered rationale for instrumentalizing women within the framework of Boko Haram's ideology and culture, arguing for a greater appreciation of how gender factors in the group's violence.
\end{abstract}

Keywords: Nigeria: Boko Haram; Terrorism; Gender; Women; Radicalisation; Tactics; Kidnapping

\section{Introduction}

The Islamist terrorist group known as Boko Haram, but whose formal name in Arabic is Jamäa Ahl al-sunnah li-da'wa wa al-jihād (Sunni Group for Preaching and Jihad), has been active in Nigeria

since 2002, when it was founded by Muhammed Yusuf (Tonwe \& Eke 2013: 234). Translated from Hausa, 'Boko Haram' means 'Western Education is Sinful', and this reflects the group's two main aims: the opposition of what it considers to be the secular westernisation of Nigeria, especially co-educational learning and democratic elections; and the creation of an Islamic state in Nigeria, or at least in the country's majority Muslim northern states (Ibid: 235).

The Nigerian government has violently opposed Boko Haram, and in July 2009 successfully, but only temporarily, quashed an uprising by the group across north-eastern Nigeria (Adesoji 2010: 98). The uprising led to the deaths of 800 Boko Haram members, including Yusuf. The extra-judicial killing of Yusuf was recorded on cell phones and the footage became widely accessible on the Internet, which only increased his "martyrdom" status in the eyes of his followers (IRIN News, 18 July 2011). One year later, in July 2010, Boko Haram's new leader, Yusuf's former second-in-command, Abubakar Shekau emerged from hiding and announced in a statement released to journalists that "jihad has begun" (Zenn 2013).

Since July 2010 Nigeria has experienced both a resurgence in Boko Haram militancy and an evolution to more sophisticated attacks and jihadist ideology, modelled on al-Qaeda (Pham 2012: 3-6). More than 3,500 people have been killed in the conflict since 2010, and after more than four years of Shekau's leadership, the violence shows no signs of abating (Agbiboa 2014: 41). Shekau has called out to other jihadist groups, including Al-Qaeda leaders, such as Ayman al-Zawahri and the late Abu Musa'ab al-Zarqawi, as well as Al-Qaeda in the Islamic Maghreb (AQIM) and Al-Shabaab. Boko Haram's international links are however not as developed as those of its splinter group of mostly AQIM-trained militants, Ansaru, which has closer operational ties to the global Al-Qaeda network (Long War Journal, 13 November 2013). 


\section{Journal of Terrorism Research}

The increasingly international character of Boko Haram has become a focus of analysis ever since Boko Haram's suicide car bombing attack on the UN Headquarters in Abuja in August 2011. This article, however, addresses a less-researched aspect of Boko Haram's activities: gender-based violence (GBV) and Boko Haram's instrumentalization of women in its operations, culture and ideology (Barkindo et al 2013: 4).

\section{GBV in Context}

GBV is defined by the UN as 'physical, sexual or mental harm or suffering to women, including threats of such acts, coercion or arbitrary deprivation of liberty, whether occurring in public or in private life' (World Health Organization). The term, however, also applies to violence specifically targeted against men and boys (UNFPA 2012: 3). 'Gender' is understood as socially constructed norms and roles both limiting, and permitting, the actions and expectations of men and women (Butler 1999: 6; Mu'Azu \& Uzoechi 2010: 122).

Within Nigeria, GBV transcends region, religion and ethnicity, with physical and sexual abuse affecting as many as 35.1\% of Igbo women and 34.3\% of Hausa-Fulani women (Oladepo et al 2011). Nigerian cultural traditions have included female genital mutilation, forced marriage and widowhood practices, including hairshaving and restriction to the home (Ifemeje 2012: 138). Nigerian law is also infused with discriminatory practices against women, including an implied legal backing to the assault of a wife in Section 55 of the penal code, and, in Section 6 of the criminal code, a lack of legal recognition for rape within marriage (Ibid.: 143) [1]. GBV also affects men in Nigeria and sexual violence has been a tactic of government forces against men in detention in order to humiliate and disempower them (Peel 2004: 65).

This analysis will specifically focus however on Boko Haram and gender, arguing that there is evidence that gender is now an increasingly significant component of Boko Haram's tactics, messaging, and violence.

The first section explores Boko Haram's recent campaign of gender-based abductions in its escalating conflict with the security forces. The second section explores tactics, and provides evidence of Boko Haram's shift to include women in its operations and the extensive targeting of Christian women. The final section considers the rationale for instrumentalizing women within the framework of Boko Haram's ideology and culture.

\section{Instrumentality: Women as Pawns}

2013 marked a significant evolution in Boko Haram's tactics. Boko Haram carried out a series of kidnappings, in which one of the main features was the instrumental use of women, in response to corresponding tactics by the Nigerian government. Kidnapping is a recent development for the group and the first suggestions of this tactic emerged in Boko Haram statements in January 2012. It was then that the group's leader, Abubakar Shekau, issued a video message threatening to kidnap the wives of government officials in response to the government imprisoning the wives of Boko Haram members (Associated Press, 27 January 2012).

However, Boko Haram's first actual kidnapping operation was carried out one year later in February 2013, with the abduction of-a seven-member French family in northern Cameroon, then brought back to Nigeria (The Guardian, 19 April 2013). The family group included four children (Ibid.). Between February 2013 and May 2013, the kidnapping strategy was brought directly to Nigerian soil, with the abductions of more than a dozen government officials and their families in Boko Haram's main base of Borno State. In May 2013, Boko Haram carried out a mass assault on a police barracks in Bama, Borno State in which militants captured 12 


\section{Journal of Terrorism Research}

Christian women and children (Agence France-Presse, 13 May 2013). This was a prolonged attack, and the abductions followed a fierce battle with security forces in which more than 100 people were killed. On May 7, 2013, Shekau claimed the kidnappings of these 12 women and children in Boko Haram's name. In another video message, he then promised to make these hostages his 'servants' if certain conditions, such as the release of Boko Haram members and their wives from prison, were not met (Agence France-Presse, video, 13 May 2013).

Shekau's statement related to the Nigerian government's arrest in 2012 of the wives and children of several Boko Haram leaders, for which the Bama kidnappings were a response. More than 100 women and children had been detained, among them Shekau's own wives. Also arrested were the wife and children of the commander for Kano, Suleiman Muhammed; the pregnant wife of the commander for Sokoto, Kabiru Sokoto, who gave birth while in prison; and the wife of the suicide-bomber who attacked the 'This Day' media house in Abuja in April 2012 (Barkindo et al 2013: 22). These arrests were not unusual in themselves. The targeting of suspects' family and friends is a common policing practice in Nigeria, according to Nigerian security experts (Interview with Beegeagle, 2013). The significance was the deliberate deployment of such practices to strike at the heart of Boko Haram through Boko Haram's female family members, which in turn has had a significant impact on Boko Haram's strategy.

This capture of Boko Haram militants' family members was cited as a grievance in almost all Shekau's video statements in 2012 and 2013. In his first statement after the mass detentions, Shekau explicitly accused the government of "kidnapping" women (YouTube, 11 January 2012). Subsequent video messages reiterated this theme, with complaints of a sustained government strategy of arrests of Boko Haram family members. When in mid-September 2012 the government detained a further ten women associated with Boko Haram, Shekau responded with his fifth video message. In this video, which was made public on September 30, 2012, Shekau threatened revenge on wives of government officials. He also speculated on the possible sexual abuse of the Boko Haram family members by security forces, when he said '...they have continued capturing our women... . In fact, they are even having sex with one of them. Allah, Allah, see us and what we are going through' (YouTube, 30 September 2012). He made clear the intention to target 'enemy' women in return, 'Since you are now holding our women, (laughs) just wait and see what will happen to your own women.. to your own wives according to Sharia law' (Ibid). These events demonstrate an established cycle of government detentions of women related to Boko Haram, and the group's retaliatory abduction of Christian women.

All these women were targeted for instrumental purposes, as none of those captured on either side had any direct involvement in the conflict. The women abducted by Boko Haram at Bama, for example, were visiting relatives working at the police station (Al-Jazeera, 26 May 2013). After they were released several weeks later in exchange for the release of the wives of Boko Haram members, the women were interviewed by Al-Jazeera. They said that the Boko Haram members told them explicitly that their abduction was a response to the government's detention of their own wives and children. They had been in 'the wrong place at the wrong time' (Ibid.).

Correspondingly, there is no evidence that the female relatives of Boko Haram members who were arrested by the government had any direct involvement in the group's activities. While Boko Haram has in the past paid young boys to carry out operations, such as arson attacks and intelligence gathering, there is no indication that women have been carrying out such activities (Punch News, 30 November 2013). Nor, according to a leading Nigerian security expert, is it probable that female relatives of Boko Haram operatives would be informed if their husband were an active Boko Haram member (Anonymous, Interviewed by Jacob Zenn, May 2013). In one case in 2012, for example, a pregnant Cameroonian woman and child were found 


\section{Journal of Terrorism Research}

in a Kano flat that also served as a Boko Haram hide-out. She appeared entirely ignorant that her husband was suspected of planning an attack on a church that killed at least twenty people (PM News Nigeria, 1 May 2012).

\section{Evolving Conflict, Evolving Tactics}

The cycle of gender-based abduction and detention and increased violence in Nigeria is evolving, and has expanded since Nigerian President Goodluck Jonathan announced a State of Emergency in Borno, Yobe and Adamawa States in May 2013 (CNN, 14 May 2013). Since 2013, the Civilian Joint Task Force (JTF) has joined security forces in employing new methods against Boko Haram, such as the mass arrest of male suspects in the early hours of the morning, the disappearance of suspects, and the use of young teenage men, fluent in the local Kanuri language and culture to operate checkpoints (Human Rights Watch News, 29 November 2013). Male supporters of Boko Haram have therefore become uniquely vulnerable to detention and abuse, particularly by the Civilian JTF, which is essentially staffed by volunteers.

Since then, a series of unusual arrests in Maiduguri, Borno state, suggests an immediate and gendered responsive shift in Boko Haram tactics. In June 2013, an AK-47, a pistol and improvised explosive devices (IEDs) were found in the garments of two 'shivering' veiled women in Maiduguri (Vanguard News, 30 June 2013). Two months later, two women hiding rifles in their clothing were among five suspected Boko Haram militants who were arrested by the security forces (The Guardian Nigeria, August 2013). Also in August 2013, a woman was detained alongside a 35-year old male Boko Haram suspect (Vanguard News, 17 August 2013). Additionally, male Boko Haram members have reportedly disguised themselves as women in veils in order to evade arrest. In one case, in July 2013, three men dressed as veiled women were killed, and around twenty others arrested, in an attempted attack on a police station (Daily Trust, 6 July 2013).

This mirrors a pattern seen in the adaptive responses of other terrorist organisations in times of unique pressure on men (Cunningham 2003: 172; Ortbals \& Poloni-Staudinger 2013: 44). In Iraq, for example, women were similarly deployed to smuggle arms and execute suicide bombings, during a clamp-down on $\mathrm{Al}$ Qaeda in the mid-2000s ( Sjoberg \& Gentry 2011: 15; Bloom 2011: 210). A direct order from the leader of alQaeda in Iraq, Abu Mus'ab al-Zarqawi, this capitalised on women's superior ability to evade security checks, cache weapons in clothing, and attract less suspicion as suicide bombers (Ibid.: 210-4). His intention was also to shame men into action (Ibid.), although there is as yet no indication of this aim within Boko Haram.

The tactical use of women due to the lesser suspicion they arouse has also been evident in Islamist violence in Pakistan and Indonesia; and within the conflict in Israel and Palestine (Ibid: 177). Historically, it is a pattern seen in liberation campaigns such as the Algerian resistance against the French, in which women were initially ordered to smuggle weapons; later, recognising the vital role they could play, female supporters of the resistance became willing volunteers for such tasks (Minne \& Clarke 2007: 344), (Horne 2002:124).

\section{Targeting and Abusing Christian Women}

The State of Emergency has manifested in other Boko Haram activities involving women, with a reported increase in GBV against Christian women in northern areas of Nigeria, and increasing levels of sexual violence including rape, torture and also murder. A recent study for Nigeria's Political Violence Research Network suggests that more than $45 \%$ of those killed by Boko Haram are Christian women and children (Barkindo et al 2013: 17-22). This, too, appears to be connected to the increased government pressure on Boko Haram in strongholds in northeastern Nigeria, with insurgents abducting Christian women as they 


\section{Journal of Terrorism Research}

flee the security forces. The Christian Association of Nigeria has been reporting the abduction of Christian teenagers since July 2013 (Agenzia Fides, 23 July 2013). Researchers speaking to women in the northeastern regions have uncovered a picture of violence and intimidation, with women increasingly targeted with kidnap, forced marriage and compulsory conversion to Islam (Barkindo et al 2013:17-29).

Some of this GBV appears tactical. In one widely reported case from November 2013, a Christian teenager told how she was abducted by Boko Haram from a rural region of Gwoza, Borno State, and forced to cook and clean for the group. This 19-year old girl, Hajja, was held for three months, during which time she was also forced to convert to Islam, set to be married to one of the group, and pressured to carry out operational tasks for the fourteen-strong team of men who took her. Hajja was made to lure government soldiers into positions where they could be targeted, and to watch as their throats were slit by Boko Haram members after they were captured-killings in which the Muslim wife of the Boko Haram cell leader reportedly participated (The Blaze, 19 November 2013). A Gwoza official estimates more than a dozen other Christian women remain in captivity in similar circumstances (Reuters, 17 November 2013), and young girls are particularly targeted (Wall St Journal, 14 January 2014).

Such practices are reminiscent of the behaviour of rebel movements in conflict zones in other parts of SubSaharan Africa, in tactically exploiting women. Civil conflicts in Mozambique, Sierra Leone and Rwanda have all witnessed GBV in the abduction, sexual violence and forced marriage and conscription of enemy women into insurgent groups (Mazurana \& McKay 2003: 11-17; Turshen 2001: 5; Coulter et al 2008: 9-12). In Uganda, soldiers with Joseph Kony's Lord's Resistance Army (LRA) were routinely engaged in the sale and 'transfer' of women (Amnesty International 1997: 17; Turshen 2000: 811-2). In these cases women were targeted both for their assets, and as 'assets' in themselves. Their value was reproductive, and productive, providing skills such as cooking and cleaning, necessary to a wartime labour force (Turshen 2001: 1). Unlike earlier civil African conflicts such as those in Eritrea or Mozambique, in which women's rights were part of the insurgent ideology, these later conflicts have predominantly only objectified and exploited women (Coulter et al 2008: 9-17).

If the abduction of women by Boko Haram is tactical, other violence against Christian women appears primarily punitive. In Maiduguri, in August 2013, a Christian student reported an attack by Boko Haram on her university accommodation: the men were murdered, the women segregated into Muslim and non-Muslims, and the Christian women systematically raped (Barkindo et al 2013: 23). Such attacks on Christian women by Boko Haram can be regarded as an extension of other institutionalised and long-term discriminatory practices against them in northern regions (Onapajo \& Uzodike 2012: 32). Women have faced broad discriminatory practices in both the professional and domestic spheres. They have been targeted in acid-attacks for 'un-Islamic' practices, such as a failure to wear the hijab, or for taking a job (Turaki 2010). Women are also often accused of 'dishonouring Islam'. In 2006, riots ensued in which more than 50 Christians were killed, mostly women and children, after a Christian female teacher confiscated a Qur'an from a student in Bauchi (Alao 2009: 40). This generic culture of discrimination against Christians has enabled the escalation in recent violence.

\section{Gender in Boko Haram's Ideology and Culture}

There have been no explicit calls in Boko Haram's ideology for this level of violence against Christian women, or women in general (Barkindo et al 2013: 5). However, Boko Haram's command to Jihad often features exhortations to terrorise Christian communities or, in its words, a "War on Christians", and the victimisation of women is a tactic within this strategy (Punch News, 11 July 2012; Coulter et al 2008: 13). 


\section{Journal of Terrorism Research}

Shariah law is also a factor. Boko Haram's emphasis on the forced imposition of Shariah facilitates GBV through rigidly gendered ideological structures (Onuoha 2010: 57). The rise of Boko Haram coincided with the adoption of Shariah in 12 northern states, and was to some extent a by-product of this (Akanji 2009: 55-60). The version of Shariah law supported by Shekau and Boko Haram promotes narrow gender roles for men and women, enforcing strict rules on women's dress and sexual conduct and instituting other discriminatory and abusive practices against women. These range from the enforced segregation of schoolchildren, to the public flogging of women for fornication (BBC,7 January 2003). Gendered norms have been adopted by Boko Haram's leaders, who have listed among the values to be opposed, '..the rights and privileges of Women, the idea of homosexualism, lesbianism.. rape of infants.. blue films, prostitution..' and beauty pageants, all associated with Western ideals (Zenn 2013b; World Stage, 18 March 2012).

Boko Haram's ideology casts men in hyper-masculine combat roles, their duty to violently oppose the west. By contrast, ..unarmed men, youths, women, cripple and even under age..' are exempt from battle and constitute illegitimate targets (Sahara Reporters, 22 January 2012). Muslim women - in contrast to Christian women - have customarily been spared, even where Boko Haram has targeted Muslim men, as in an attack on a college in Yobe in September 2013. All male students were killed, but female students were not (International Business Times, 29 September 2013). This binary understanding of gender norms permits GBV to serve as a display of power (Solangon \& Patel 2012: 425). Abuses of Christian women both serve to mark their difference from Muslim women, and strike at Christian men, by demonstrating their inability to protect 'their' women.

This combative ideological masculinity appears to have specific resonance with a section of disenfranchised Nigerian men. It was predominantly such men who gathered to watch Boko Haram's founder, Muhammed Yusuf, when he spoke in television interviews, or simply led Friday prayers. Yusuf's appeal was to a population dominated by unemployed, poor males (Onuoha 2010: 57-8). These men were angry and frustrated over the perceived corruption of the Nigerian government, on which Yusuf lectured, and mass unemployment (IRIN News, 18 July 2011).

Globalisation can be regarded as a factor in such violence and feelings of grievance, with the fracturing of men's traditional identities impacting on their willingness to turn to extremist groups (Connell 2005: 73; Maalouf 1996: 90-93). In the face of social change, the reform of traditional gendered practices and the gradual adoption of 'Western' values, gender-based violence and binary gender norms can perform as a source of self-worth (Barker \& Ricardo 2005: v; Kimmel 2003: 603-620). These norms are not a necessary characteristic of Islamist groups. Nigeria's earlier Islamist movement Yan Izala, established in 1978, in fact promoted an emancipatory programme of rights for women, when compared with some other Salafist movements (Loimeier 2012: 141).

The impact of grievances, globalisation and poverty on Nigerian violence suggests that ideology is one of a number of possible factors in GBV committed by Boko Haram members and supporters. Indeed, Alao proposes that Nigerian radicalisation predominantly concerns matters of ethnicity, commercial rivalries and power (Alao 2009: 22). Agbiboa also cites local disputes, poverty, corruption and long-term injustices committed without police action as drivers for religious and ethnic violence (Agbiboa 2014: 50).

Criminal motives may also play a role. In Maiduguri, six Christian women were abducted and repeatedly raped by insurgents who claimed this as sexual 'jizya', a tax paid by Christians under Islamic law. However, the surname of one of the women distinguished the group as ethnic Berom, who are perceived by Boko Haram as "immigrants" to northern Islamic lands. The rape therefore effectively served as a punishment, and a threat to leave (Barkindo et al 2013: 23). In other sexual attacks against women, the victims' perception 
has been that the assaults were driven by an essentially 'criminal' element of the group (Ibid. p.29). Indeed, ideology is unlikely to drive all Boko Haram members, as some are undoubtedly coerced into joining the group (AOV \& NWGOV 2013: 43). The level of control of Boko Haram leadership over the activities of such elements is questionable, and has as yet not been pronounced upon by Shekau.

\section{Conclusion}

This article focused on Boko Haram, with the aim of shedding light on a neglected but developing aspect of the group's operations: gender-based changes in Boko Haram's tactics and its instrumental use of women, resulting in increasing GBV targeted at Christians. It outlined the instrumental use of women by both Boko Haram and Nigerian security forces in a cycle of abductions and detentions dating from 2012. Three conclusions can be drawn from these retaliatory actions.

Firstly, as implied by Shekau's video messages, abductions of women have since 2012 come to constitute a semi-official Boko Haram tactic, in response to similar tactics by government. Secondly, it seems clear that the recent violence and ensuing state of emergency is causing Boko Haram to evolve tactically, engaging women in support roles in the group, disguising men as women to avoid arrest, and abducting Christian women. Thirdly, women are being targeted by both sides in Nigeria's conflict, for purely instrumental reasons. They do not yet appear to be actively and willingly participating in violence to a significant extent. The article also briefly explored the complex factors in the evolution of Boko Haram's tactics. Shariah law, at the heart of Boko Haram, and with a strict control and restriction of women's liberty is implicated in GBV, but other factors emerge. Local grievances and frustrations drive men towards Boko Haram, and a sense of security in its gender norms; perhaps also to GBV. Women victims themselves suggest criminality is a factor in GBV, with women stripped of assets, or raped as an end in itself. Additionally, GBV by Boko Haram is contextualised by an institutionalisation of broader discriminatory practices within Nigeria, but also by the similar sexual targeting of women in other civil conflicts in sub-Saharan Africa, where women are constructed as assets, and exploited as such, and by similar tactical developments in other terrorist groups when under extreme pressure.

It is also important to note that, although this piece focused on Boko Haram, the group does not have a monopoly on violence against women in Nigeria. Government troops have also been accused of looting, theft, murder and rape (IRIN News, 18 July 2011). It is hard to envisage an end to Boko Haram's violence, while government forces employ violence with impunity. Nor while discriminatory practices remain to some extent endemic. This is not to discount the activities of the many proactive Nigerian women; Nigerian women's groups have indeed been a powerful voice in protesting violence (Patch 2008: 40).

This analysis is still limited by the lack of research carried out with women supporters of Boko Haram. More research is needed with women in Boko Haram strongholds to ascertain their views. However, the strict gender norms of Boko Haram suggest that if women do carry out operations for the group, this is unlikely to constitute more than an emergency measure, and will not affect women's status organisationally. This is consistent with current trends in other terrorist groups (Global Observatory, 21 August 2013).

It is hoped that this piece has made clear that gender norms do figure in the Nigerian conflict, and within Boko Haram's culture, activities and ideology specifically. This article aims to provide an introduction to the importance of a further exploration of gender within the group, as a path to understanding, and ultimately preventing, Nigeria’s ongoing and escalating violence. 


\section{Journal of Terrorism Research}

\section{About the authors}

Jacob Zenn is an analyst of African and Eurasian Affairs for The Jamestown Foundation in Washington DC and a legal adviser on international law of freedom of association. He authored "Northern Nigeria's Boko Haram: The Prize in Al-Qaeda's Africa's Strategy" in 2012 and currently consults on countering violent extremism in West Africa and Central Asia.jacobzenn@gmail.com

Elizabeth Pearson has recently completed an MA in International Conflict Studies in the War Studies Department at King's College London, where she was a Simon O'Dwyer Russell Prize-winner 2012-13. Her research interests are radicalisation, gender and terrorism, and her MA dissertation examined the question, 'How does the UK's Counter-Radicalisation strategy Prevent understand gender?' Elizabeth also has more than fifteen years experience as a radio producer, reporter and feature-maker, and works freelance, mainly for BBC Radio Four. www.lizzpearson.com

\section{Notes}

[1] The criminal code was enacted in 1945, the penal code in 1960

\section{Bibliography}

Action on Armed Violence, and the Working Group on Armed Violence (2013), The Violent Road, An Overview of Armed Violence in Nigeria via http://aoav.org.uk/2013/the-violent-road-nigeria-north-east/ Adesoji, Abimbola (2010), 'The Boko Haram Uprising and Islamic Revivalism in Nigeria', Africa Spectrum, Vol. 45 No. 2, pp. $95-108$

Agbiboa, Daniel E. (2014), 'Peace at Daggers Drawn? Boko Haram and the State of Emergency in Nigeria', Studies in Conflict \& Terrorism, Vol.37, No.1, pp.41-67

Agence France-Presse, 13 May 2013, 'New Boko Haram video claims attacks, shows hostages', via http:// mg.co.za/article/2013-05-13-new-boko-haram-video-claims-attack-shows-hostages accessed 9/1/2014

Agence France-Presse, Video, 13 May 2013, 'Nigeria Islamist video claims attacks, shows hostages', via http:// www.youtube.com/watch?v=n6qZM36oq8E

Agenzia Fides, 23 July 2013, 'Boko Haram: Christian girls kidnapped and Islamized, schools targeted', via http://www.fides.org/en/news/34019-AFRICA NIGERIA Boko Haram Christian girls kidnapped and Islamized schools targeted\#.UuOvF7TLdLN accessed 24/1/2014

Al-Jazeera News, 26 May 2013, 'Freed Nigerian Hostages Tell of Ordeal' via http://www.youtube.com/ watch?v=36Vlok6GrKQ

Akanji, Olajide O (2009), 'The politics of combating domestic terrorism in Nigeria, in Wafula Okumu and Anneli Botha (eds), Domestic terrorism in Africa: defining, addressing and understanding its impact on human security, (Pretoria: Institute for Security Studies)

Alao, Abiodun (2009), 'Islamic radicalization and violence in Nigeria: A country report', Security and Development, via http://www.securityanddevelopment.org/pdf/ESRC\%20 Nigeria\%200verview.pdf

Amnesty International Report (1997), Uganda: "Breaking God's Commands": the Destruction of Childhood by the Lord's Resistance Army, (New York: Amnesty International)

Amnesty International Report (2012), Nigeria: Trapped in the Cycle of Violence, (London: Amnesty 


\section{Journal of Terrorism Research}

International)

Associated Press, 27 January 2012, 'Nigeria sect leader threatens new attacks' via http://www.utsandiego.com/ news/2012/jan/27/nigeria-sect-leader-threatens-new-attacks/all/?print accessed 10/1/2014

Barker, Gary and Ricardo, Christine (2005), 'Young Men and the Construction of Masculinity in Sub-Saharan Africa:Implications for HIV/AIDS, Conflict, and Violence', Social Development Papers: Conflict, Development and Reconstruction, (The World Bank) Paper No. 26

Barkindo, Atta, Gudaku, Benjamin Tyavkase, Wesley, Caroline Katgurum (2013), 'Boko Haram and Gender Based Violence Against Christian Women and Children in North-Eastern Nigeria Since 1999', NPVRN Working Paper No. 1, (Amsterdam: Open Doors International)

BBC News, 7 January 2003, 'Analysis: Nigeria’s Sharia split' via http://news.bbc.co.uk/1/hi/world/ africa/2632939.stm

Bloom, Mia (2011), Bombshell, The Many Faces of Women Terrorists, (C. Hurst and Co.: London)

Butler, Judith (1999), Gender Trouble: Feminism and the Subversion of Identity, (Routledge Classics: London) CNN, 14 May 2013, 'Nigerian President declares emergency in 3 states during "rebellion"” via http://edition. cnn.com/2013/05/14/world/africa/nigeria-violence/ accessed 13/1/2014

Connell, Robert W. (2005), 'Globalisation, Imperialism and Masculinities', in Kimmel, Michael, Hearn, Jeff and Connell, Robert W. (Eds.) A Handbook of Studies on Men and Masculinities, (Sage)

Coulter, Chris, Persson, Mariam and Utas, Mats (2008), Young Female Fighters in African Wars, Conflict and Its Consequences, (Nordiska Afrikainstitutet : Stockholm)

Cunningham, Karla J. (2003), 'Cross-Regional Trends in Female Terrorism', Studies in Conflict \& Terrorism, Vol.26, No.3, pp.171-195

Daily Trust, 6 July 2013, 'Nigeria: women as Boko Haram's new face’ via http://allafrica.com/ stories/201307081607.html accessed 12/1/2014

Danjibo, D. N. (2009), 'Islamic Fundamentalism and Sectarian Violence: The "Maitatsine" and "Boko Haram" Crises in Northern Nigeria. Peace and Conflict Studies Programme', Institute of African Studies, (University of Ibadan) via http://www.ifra-nigeria.org/IMG/pdf/N- D- DANJIBO - Islamic Fundamentalism and Sectarian Violence The Maitatsine and Boko Haram Crises in Northern Nigeria.pdf (accessed

Fawole, O.I., Ajuwon, A.J, Osungbade, K.O. \& Fawega, C.O. (2002), 'Prevalence and nature of violence to young female hawkers in Motor parks in South Western Nigeria', Health Education Research, 102:230-238.

Global Observatory, 21 August 2013, 'Women Terrorists Today Follow Men’s Ideologies: Interview with Mia Bloom' via http://www.theglobalobservatory.org/interviews/563-women-terrorists-today-follow-mensideologies-interview-with-mia-bloom.html

The Guardian, 19 April 2013, 'French family seized in Cameroon by suspected Boko Haram Islamists freed' via http://www.theguardian.com/world/2013/apr/19/french-family-kidnapped-cameroon-freed accessed $9 / 1 / 2014$

The Guardian Nigeria, August 2013, 'JTF, vigilance group capture five suspected terrorists' via http://www. theguardianmobile.com/readNewsItem1.php?nid=16303 accessed 12/1/2014

Horne, Alistair (2002 reprint) [1977 original], A Savage War of Peace: Algeria 1954-1962, (London: Pan Macmillan).

Human Rights Watch News, 29 November 2013, 'Boko Haram abducts women, recruits children’ via http:// 


\section{Journal of Terrorism Research}

www.hrw.org/news/2013/11/29/nigeria-boko-haram-abducts-women-recruits-children accessed 13/1/2014

Ifemeje, Sylvia Chika,(2008), 'A critique of gender discriminatory practices in Igbo customary marriages', Journal of Women and Minority Rights, Vol.1, No.1, pp.57-61.

Ifemeje, Sylvia Chika (2012), 'Gender-Based Domestic Violence in Nigeria: A Socio-Legal Perspective', Indian Journal of Gender Studies, Vol. 19, No.1, pp. 137-148

Igbellina-Igbokwe, Nkiru, (2013), 'Contextualizing Gender Based Violence Within Patriarchy in Nigeria', Pan-African Voices for Freedom and Justice (Pambazuka News), Issue 632, via http://www.pambazuka.org/en/ category/features/87597.

IRIN News, 18 July 2011, 'Analysis: Understanding Nigeria’s Boko Haram radicals' via http://www.irinnews. org/report/93250/analysis-understanding-nigeria-s-boko-haram-radicals

International Business Times, 29 September 2013, 'Boko Haram slaughter 50 students in Nigeria college dorm' via http://www.ibtimes.com/boko-haram-militants-slaughter-50-students-nigeria-college-

dorm-1412504

Johnmary, Ani Kelechi (2012), 'Violent Traditional Gender Practices and Implications for Nation Building Process in Nigeria, Public Policy and Administration Research, Vol. 2, No. 5, pp. 44-56.

Kimmel, Michael S. (2003), Globalization and its Mal(e)Contents : The Gendered Moral and Political Economy of Terrorism, International Sociology, Vol.18, pp.603-620

Loimeier, Roman (2012), 'Boko Haram : The Development of a Militant Religious Movement in Nigeria', Africa Spectrum, Vol.47, Nos. 2-3, pp. 137-155

Long War Journal, 13 November 2013, 'US adds Boko Haram, Ansaru to list of foreign terrorist groups' via http://www.longwarjournal.org/archives/2013/11/us adds boko haram t 1.php\#ixzz2rVxy4jHh

Maaluf, Amin (1996), In the Name of Identity: Violence and the Need to Belong, (Penguin: London)

Mazurana, Dyan and McKay, Susan (2003), Girls in Fighting Forces in Northern Uganda, Sierra Leone, and Mozambique, Policy and Program Recommendations, (International Centre for Human Rights and Democratic Development and University of Wyoming and the University of Montana)

Minne, Danièle Djamila Amrane \& Clarke, Alistair (translation) (2007), 'Women at War', Interventions: International Journal of Postcolonial Studies, Vol.9, No.3, pp. 340-349

Mu'azu M. T. and Uzoechi B. C. (2010) 'Gender Issues in Curriculum Implementation at the Basic Education Level in Nigeria', Nigerian Journal of Curriculum Studies, Vol. 17. No. 3, p. 122

Okpaga1, Adagba, Chijioke, Ugwu Sam, Okechukwu, Eme Innocent (2012), 'Activities of Boko Haram and Insecurity Question in Nigeria', Arabian Journal of Business and Management Review, Vol. 1, No.9

Oladepo, Yusuf OB, and Arulogun OS (2011), 'Factors Influencing Gender Based Violence Among Men and Women in Selected States in Nigeria', African Journal of Reproductive Health December 15(4):78-86.

Onapajo, Hakeem \& Uzodike, Ufo Okeke (2012), 'Boko Haram terrorism in Nigeria', African Security Review, Vol. 21, No.3, pp.24-39

Onuoha, Freedom C (2010), 'The Islamist challenge: Nigeria's Boko Haram crisis explained', African Security Review, Vol.19, No.2, pp. 54-67

Ortbals, Candice D. and Poloni-Staudinger, Lori (2013), Terrorism and Violent Conflict: Women's Agency, Leadership and Responses, (Springer: New York)

Patch, Jonathan (2008), 'Women and Non-violent Forms of Activism in the Niger Delta Oil Resource 
Conflict', Undercurrent, Vol. 5, No.3 p.39

Peel, Michael (2004), 'Men as Perpetrators and Victims', in Rape as a Method of Torture, ed. Michael Peel. (London: Medical Foundation for the Care of Victims of Torture) pp.61-70.

Pham, J. Peter (2012), 'Boko Haram’s Evolving Threat', Africa Security Brief, Vol. 20, pp.1-8 (African Center of Strategic Studies), via www.ndu.edu/press/lib/pdf/Africa-Security-Brief/ASB-20.pdf accessed 10/1/2014

Pew Research (2009), 'Mapping the Global Muslim Population: A report on the size and distribution of the World Muslim Population', accessed via http://www.pewforum.org/newassets/images/reports/ Muslimpopulation/Muslimpopulation.pdf accessed 22/3/2013

PM News Nigeria, 1 May 2012, 'Cameroonian among women captured during Kano JTF raid' via http:// pmnewsnigeria.com/2012/05/01/cameroonian-among-women-captured-during-kano-jtf-raid/ accessed $10 / 1 / 2014$

Punch News, 11 July 2012, 'We're behind plateau mass killings - Boko Haram' via http://www.punchng.com/ news/were-behind-plateau-mass-killings-boko-haram-\%E2\%80\%A2-says-christians-should-accept-islam-ifthey-want-peace/

Punch News, 30 November 2013, 'Boko Haram paid us only N5000 each, to burn schools' via http://www. punchng.com/news/b-haram-recruits-children-for-attacks-hrw/

Reuters, 17 November 2013, 'Insight: Boko Haram, taking to hills, seize slave 'brides"' via http://www.reuters. com/article/2013/11/17/us-nigeria-security-islamists-insight-idUSBRE9AG04120131117 accessed 24/1/2014

Sahara Reporters, 22 January 2012, 'Boko Haram: why we struck in Kano’ via http://saharareporters.com/ news-page/boko-haram-why-we-struck-kano

Schweitzer, Yoram (2006), 'Dying for Equality?', Memorandum 84 (Tel Aviv: Jaffee Center for Strategic Studies), pp. 8

Sjoberg, Laura and Gentry, Caron (2011), 'Introduction', in Sjoberg, Laura and Gentry, Caron E. (eds.) Women, Gender and Terrorism (University of Georgia Press: Georgia)

Smelser, Neil J. (2007), The Faces of Terrorism: Social and Psychological Dimensions, (Princeton: Princeton University Press)

Solangon, S., \& Patel, Preeti (2012), 'Sexual violence against men in countries affected by armed conflict', Conflict, Security \& Development, Vol. 12, No. (4), pp.417-442

The Blaze, 19 November 2013, 'Nigerian Terrorists Reportedly Abducting Christian Women, Forcing them to Convert and Then Marry Islamic Militants' via http://www.theblaze.com/stories/2013/11/19/nigerianterrorists-reportedly-abducting-christian-women-forcing-them-to-convert-and-then-marry-islamicmilitants/ accessed 24/1/2014

Tonwe, Daniel A. and Eke, Surulola J. (2013), 'State fragility and violent uprisings in Nigeria', African Security Review, Vol. 22, No. 4, pp. 232-243

Turaki, Yusufu (2010), Tainted Legacy: Islam, Colonialism and Slavery in Northern Nigeria, (McLean,VA)

Turshen, Meredeth (2000), 'The Political Economy of Violence against Women During Armed Conflict in Uganda', Social Research, Vol. 67, No. 3, pp. 803-824

Turshen, Meredeth (2001), 'The Political Economy of Rape: An Analysis of Systematic Rape and Sexual Abuse of Women During Armed Conflict in Africa, in C. Moser and F. Clarke eds. Victors, Perpetrators or 


\section{Journal of Terrorism Research}

Actors: Gender, Armed Conflict and Political Violence, pp. 55-68. (Zed Books: London)

United Nations Population Fund (2012), Addressing Gender-based Violence, via www.unfpa.org/.../ documents/.../final\%20sexual\%20violence\%20CSW\%...

Vanguard News, 30 June 2013, 'Vigilante arrests two women with assault rifle, IEDs in Maiduguri', via http:// www.vanguardngr.com/2013/06/vigilante-arrests-2-women-with-assault-weapons-ied-in-maiduguri/ accessed 12/1/2014

Vanguard News, 17 August 2013, 'JTR, Vigilante Arrest Female Boko Haram Suspects' via http://www. vanguardngr.com/2013/08/jtf-vigilante-arrest-female-boko-haram-suspects/ accessed 26/1/2014

Vanguard News, 28 October 2013, Nigeria, Borno cautions 'Civilian JTF' against abuse of power, 28 October 2013 via http://www.vanguardngr.com/2013/10/borno-cautions-civilian-jtf-abuse-power/

Wall Street Journal, 14 January 2014, Nigeria rebels drag children into battle, via http://online.wsj.com/news/ articles/SB10001424052702304773104579269781352679364 accessed 15/1/2014

Wendt, Alexander (1987), 'The Agent-Structure Problem in International Relations Theory', International Organization, Vol. 41, No. 3, pp. 335-370

World Health Organization, 'Health topics, Violence Against Women' via http://www.who.int/topics/gender based violence/en/

World Stage, 18 March 2012, 'Boko Haram Menace, Why is the World not Listening to this Man’ via http:// www.worldstagegroup.com/worldstagenew/index.php?active=news\&newscid $=4200 \&$ catid $=23$

YouTube, 11 January 2012, 'Message to Jonathan from Abubaker Shekau' (translation) via http://www. youtube.com/watch? $\mathrm{v}=\mathrm{eNg} 73 \mathrm{vN} 86 \mathrm{~K} 8$

YouTube, 30 September 2012, 'A Message to the World' via http://www.youtube.com/ watch? $\mathrm{v}=\mathrm{txUJCOKTIuk \& sns=em}$

Zenn, Jacob (2013), Boko Haram's Recruitment Strategies, Combating Terrorism Center, via http://www.ctc. usma.edu/posts/boko-harams-international-connections

Zenn, Jacob (2013b), 'Boko Haram Recruitment Strategies', John Campbell Blog, (Council on Foreign Relations) via http://blogs.cfr.org/campbell/2013/04/16/boko-haram-recruitment-strategies/ 